\title{
Study on Transmission Torque Characteristics of a Surface-Permanent-Magnet-Type Magnetic Gear
}

\author{
Noboru Niguchi Member (Osaka University) \\ Katsuhiro Hirata Senior Member (Osaka University) \\ Yuichi Hayakawa Student Member (Osaka University)
}

Keywords: cogging torque, finite element method, magnetic gear, skew

Magnetic gears have some advantages such as low mechanical loss and maintenance-free operation that are not observed in conventional mechanical gears. In addition, magnetic gears have inherent overload protection. Therefore, magnetic gears are expected to be used in special applications; for example, they can be used in a joint of a humanoid robot. Recently, various types of new magnetic gears have been proposed. A surface-permanent-magnettype (SPM-type) magnetic gear employing harmonic magnetic flux (Fig. 1) has gained attention because of its high transmission torque density, though it has a complex structure with multipole magnets. Some studies on an SPM-type magnetic gear have been carried out, but there are few papers on cogging torque. This paper describes the transmission torque characteristics of an SPM-type magnetic gear.

The orders of the cogging torque listed in Table 1 are obtained by applying the principle of transformation of magnetic energy to mechanical energy. In this table, $N_{s}$ is the number of stationary pole pieces, and $N_{h}$ and $N_{l}$ are the number of pole pairs in the high- and low-speed rotor, respectively. In this study, the following values were selected: $N_{s}=14, N_{h}=4$, and $N_{l}=10$.

In order to verify these orders, the 3-D finite element method (FEM) was employed. Furthermore, measurements were carried out on a prototype.

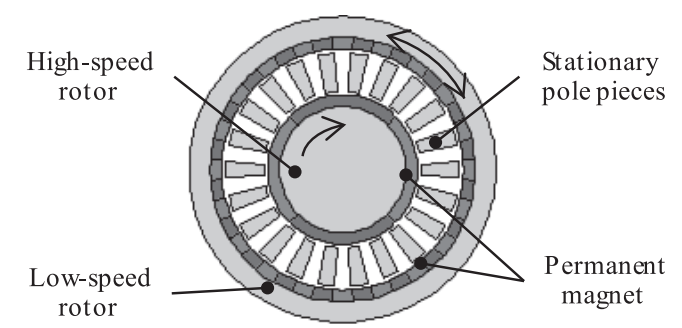

Fig. 1. SPM-type magnetic gear

Table 1. Orders of the cogging torque and constraints

\begin{tabular}{c|c|c}
\hline & $\begin{array}{c}\text { Orders of } \\
\text { the cogging torque }\end{array}$ & Constraint \\
\hline \multirow{2}{*}{$\begin{array}{c}\text { High-speed } \\
\text { rotor }\end{array}$} & $m\left(N_{l}-G_{r} N_{l}\right)$ & $n N_{h}=m\left(N_{l}-G_{r} N_{l}\right)$ \\
\cline { 2 - 3 } & $m N_{s}$ & $2 n N_{h}=m N_{s}$ \\
\hline $\begin{array}{c}\text { Low-speed } \\
\text { rotor }\end{array}$ & $m\left(N_{l}-G_{r} N_{l}\right)$ & $n N_{h}=m\left(N_{l}-G_{r} N_{l}\right)$ \\
\cline { 2 - 3 } & $m N_{s}$ & $2 n N_{l}=m N_{s}$ \\
\hline
\end{tabular}

Figs. 2 and 3 show the orders of the computed and measured cogging torques of the high-speed rotor, respectively. The orders for both sets of results are listed in Table 1.

The harmonic component (H. C.) due to the stationary pole pieces and pole pairs were obtained. These components were present because of the errors of the mesh in 3-D FEM and the noise of AC servo motor in torque measuring system.

The orders of the cogging torque of the low-speed rotor were also computed and measured. These orders are listed in Table 1. Thus, the orders contained in the cogging torque in the high- and lowspeed rotors were verified by employing 3-D FEM and by carrying out measurements on a prototype.

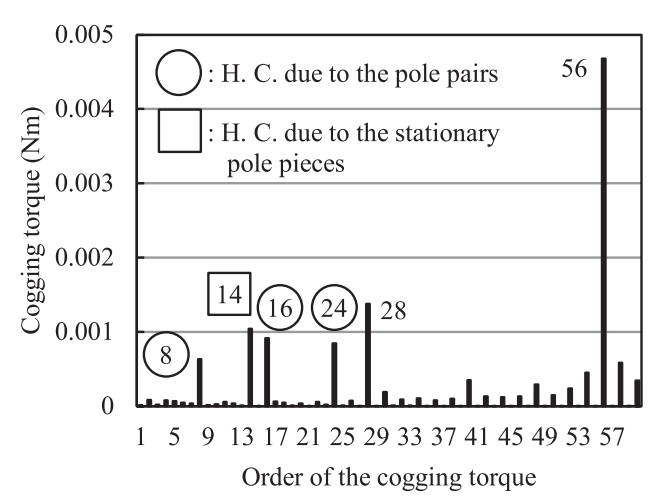

Fig. 2. Orders of the analyzed cogging torque

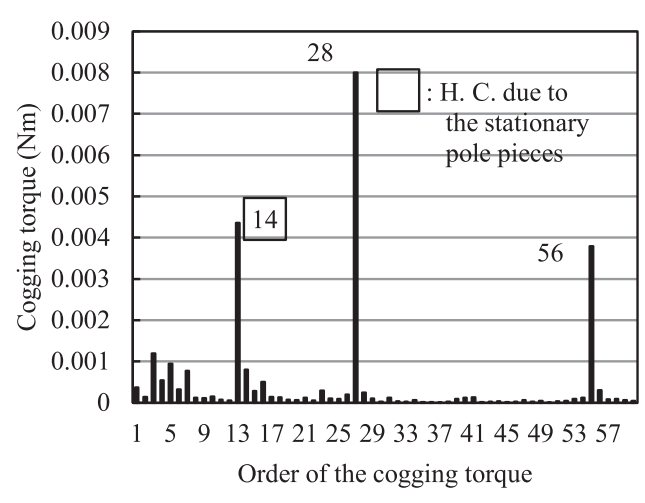

Fig. 3. Orders of the measured cogging torque 


\title{
表面磁石型磁気減速機の伝達トルク特性に関する研究
}

\author{
正 員 新口 昇* 上級会員 平田 勝弘* \\ 学生員 早川 裕一*
}

\section{Study on Transmission Torque Characteristics of a Surface-Permanent-Magnet-Type Magnetic Gear}

Noboru Niguchi*, Member, Katsuhiro Hirata*, Senior Member, Yuichi Hayakawa*, Student Member

\begin{abstract}
Magnetic gears have some advantages such as low mechanical loss and maintenance-free operation that are not observed in conventional mechanical gears. In addition, magnetic gears have inherent overload protection. Therefore, magnetic gears are expected to be used in special applications; for example, they can be used in a joint of a humanoid robot. Recently, various types of new magnetic gears have been proposed. Among these new gears, a surface-permanent-magnet-type (SPM-type) magnetic gear employing harmonic magnetic flux has gained attention because of its high transmission torque density, though it has a complex structure with multipole magnets. Some studies on an SPM-type magnetic gear have been carried out, but there are few papers on cogging torque. This paper describes the transmission torque characteristics of an SPM-type magnetic gear. The operating principle and the transmission torque under synchronous operation are formulated in accordance with the gear ratio. High orders of the cogging torque are computed by employing the 3-D finite element method, and the validity of the analysis is verified by carrying out measurements on a prototype. Furthermore, a method for reducing the cogging torque is discussed.
\end{abstract}

キーワード：磁気減速機, コギングトルク，有限要素法，スキュー

Keywords: cogging torque, finite element method, magnetic gear, skew

\section{1. 緒言}

従来の機械式減速機は，摩擦によりトルクを伝達してい るため摩耗が発生し, 定期的にメンテナンスが必要であっ た。しかし，磁気減速機は，非接触でトルクを伝達するた め，メンテナンスフリーを実現可能である。また，トルク リミッタ機能も併せ持つため, 過負荷時には脱調現象が発 生し，伝達機構の損傷防止や人命保護に効果的である。

例えば，従来の機械式平歯車を磁気減速機に置き換える と Fig. 1 のような構造になり, 非接触でのトルク伝達が可 能となる。このように，ロボットの関節など，用途を特定 すれば従来の機械式減速機に比べてメリットが多い磁気減 速機であるが, 磁石同士の対向部近傍以外は動作点が低い ため，実用的な伝達トルクが得られなかった。

しかし，フェライト磁石よりはるかに大きいエネルギー 積を持つ希土類ネオジウム磁石が開発され, さらに磁石の

\footnotetext{
* 大阪大学 大学院工学研究科 知能 - 機能創成工学専攻

于565-0871 吹田市山田丘 2-1

Dept. of Adaptive Machine Systems, Graduate School of Engineering, Osaka University

2-1, Yamadaoka, Suita 565-0871
}

動作点を高める構造と同時に, 高調波磁束を利用した減速 原理が開発されたため, 実用的な伝達卜ルクが得られるよ うになってきた。

これまで様々なタイプの磁気減速機が提案されてきた (1) (6) が, それぞれ利点・尔が存在する。その中でも Fig. 2 に 示す表面磁石型磁気減速機は, 高速ロー夕, 低速ロータお よび固定磁極片から構成され, 多極で複雑な構造にもかか わらず，伝達トルク密度が高いという優位性を持つ。した がって，これまで表面磁石型磁気減速機に関する様々な研 究が行われてきた。しかし, 高伝達トルク密度化に関する 研究は多いが，伝達時の特性に大きく影響を与えるコギン グトルクに関する研究はほとんど見かけない(7)。

ここではまず，コギングトルクの定式化を行い，含有次

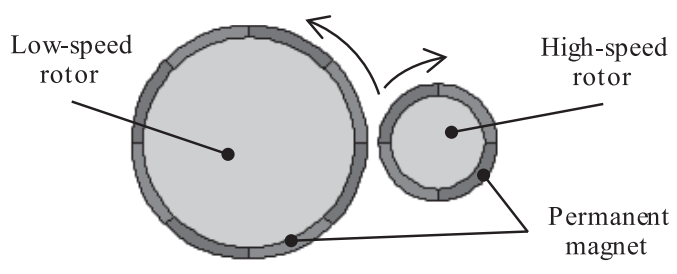

Fig. 1. Conventional magnetic gear. 


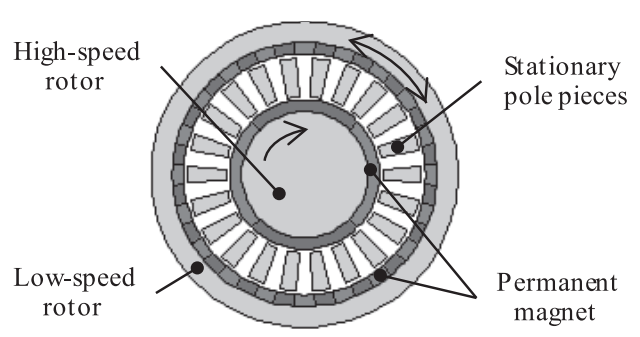

Fig. 2. Magnetic harmonic gear.

数成分を明確化した。次に 3 次元有限要素解析と試作機に よる実験にて，それらの検証を行った。そして，コギング トルクの低減手法について検証を行ったので報告する。

\section{2. 動作原理}

低速ロー夕を取り除いたと仮定すると，高速ロー夕の永 久磁石は Fig. 3(a) に示す起磁力分布を生成し, 固定磁極片 は Fig. 3(b) に示すパーミアンス分布を生成する。なお，こ こで $\theta$ はそれぞれの周方向位置を表す。

次に $F(\theta)$ と $R(\theta)$ をフーリ工級数展開すると, (1), (2) 式 が得られる。

$$
\begin{aligned}
& F(\theta)=\sum_{m=1}^{\infty} a_{m} \sin \left\{(2 m-1) N_{h} \theta\right\} \cdots \\
& R(\theta)=R_{o}+\sum_{l=1}^{\infty} a_{l} \sin \left\{(2 l-1) N_{s} \theta\right\}
\end{aligned}
$$

ここで, $N_{h}$ : 高速ロー夕の極対数, $N_{s}$ : 固定磁極片数, $l$, $m:$ 正の整数を表す。したがって, 固定磁極片外側の磁束 $\phi(\theta)$ は, (3) 式で表される。

$$
\begin{aligned}
\phi(\theta)= & \sum_{m=1}^{\infty} a_{m} R_{0} \sin \left\{(2 m-1) N_{h} \theta\right\} \\
& +\sum_{l=1}^{\infty} \sum_{m=1}^{\infty} a_{l} a_{m}\left[\cos \left\{(2 l-1) N_{s}-(2 m-1) N_{h}\right\} \theta\right. \\
& \left.-\cos \left\{(2 l-1) N_{s}+(2 m-1) N_{h}\right\} \theta\right] \cdots \cdots(3)
\end{aligned}
$$

(3) 式より, 磁束 $\phi(\theta)$ には (4) 式に示す $H_{1}(m), H_{2}(l, m)$, $H_{3}(l, m)$ 次が含まれることがわかる。

$$
\left\{\begin{array}{l}
H_{1}(m)=(2 m-1) N_{h} \\
H_{2}(l, m)=(2 l-1) N_{s}-(2 m-1) N_{h} \\
H_{3}(l, m)=(2 l-1) N_{s}+(2 m-1) N_{h}
\end{array}\right.
$$

ここで, 高速ロー夕と固定磁極片を合わせた構造は, $H_{1}(m)$, $H_{2}(l, m), H_{3}(l, m)$ 極対の永久磁石とみなしてよい。

次に高速ロー夕を $\Delta \theta$ 回転させたとき, 磁束 $\phi(\theta)$ は (5) 式で表される。

$$
\begin{aligned}
\phi(\theta)= & \sum_{m=1}^{\infty} a_{m} R_{0} \sin \left\{H_{1}(m)(\theta+\Delta \theta)\right\} \\
& +\sum_{l=1}^{\infty} \sum_{m=1}^{\infty} a_{l} a_{m}\left[\cos \left\{H_{2}(l, m)\left(\theta-\frac{H_{1}(m) \Delta \theta}{H_{2}(l, m)}\right)\right\}\right.
\end{aligned}
$$

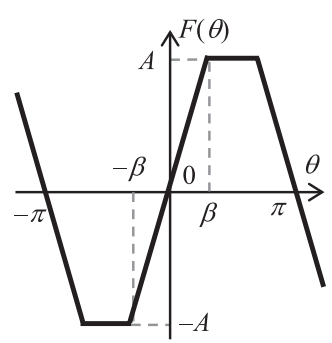

(a)

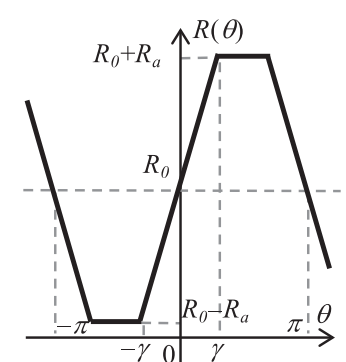

(b)
Fig. 3. Distributions of (a) magnetomotive force, and (b) permeance.

$$
\left.-\cos \left\{H_{3}(l, m)\left(\theta+\frac{H_{1}(m) \Delta \theta}{H_{3}(l, m)}\right)\right\}\right] .
$$

(5) 式より, $H_{1}(m), H_{2}(l, m), H_{3}(l, m)$ 次の磁束は, それ ぞれ $\Delta \theta,-H_{1}(m) \Delta \theta / H_{2}(l, m), H_{1}(m) \Delta \theta / H_{3}(l, m)$ 回転する ことがわかる。減速機として機能するためには, 低速口ー 夕の極対数 $N_{l}$ は $H_{2}(l, m)$ もしくは $H_{3}(l, m)$ に等しくなけ ればならない。したがって， $N_{h}, N_{s}, N_{l}$ の間には，(6) 式 が成立する必要があり，このときの減速比は，(7)式で表さ れる。

$$
\begin{aligned}
& (2 l-1) N_{s}=N_{l} \pm(2 m-1) N_{h} \\
& G_{r}=\mp \frac{(2 m-1) N_{h}}{N_{l}} \cdots \cdots \ldots . . .
\end{aligned}
$$

\section{3. コギングトルク次数}

減速比に従った同期運転時の高速ロータのコギングトル ク $T(\theta)$ を, 本節で扱う。 $T(\theta)$ は, 固定磁極片によるコギン グトルク $T_{1}(\theta)$ と低速ロー夕と固定磁極片から生成された 高調波磁束によるコギングトルク $T_{2}(\theta)$ により構成される。 磁気エネルギーから機械エネルギーへの变換則により, (8) 式が得られる。

$$
T(\theta)=-\frac{\partial W(\theta)}{\partial \theta}
$$

ここで, $W(\theta)$ は磁気エネルギーを表す。磁気エネルギー は, 磁気抵抗が大きいエアギャップ中のみに蓄えられると 仮定すると，W( $\theta)$ は (9) 式で表される。

$$
W(\theta)=\frac{1}{2 \mu_{0}} \int_{V} B^{2} d V
$$

ここで, $\mu_{0}$ : 真空の透磁率, $V:$ エアギャップの体積, $B$ : エアギャップ中の磁束密度を表す。

高速ロー夕の初期位置を $\theta=0$ として, 高速ロー夕の回 転角度を $\delta$ で表す。このとき，(9) 式は，(10) 式で表される エアギャップの体積の微小変化量 $\Delta V$ を用いて, (11) 式に 変形できる。

$$
\begin{aligned}
& \Delta V=L_{s} l_{g 1}\left(2 r_{g 1} \pi \times \frac{d \delta}{2 \pi}\right)=L_{s} l_{g 1} r_{g 1} d \delta . . . \\
& W(\theta)=\frac{L_{s} l_{g 1} r_{g 1}}{2 \mu_{0}} \oint B^{2} d \delta \ldots \ldots \ldots \ldots . .
\end{aligned}
$$




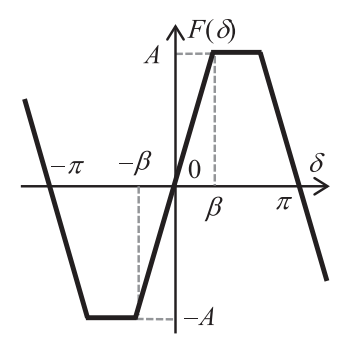

(a)

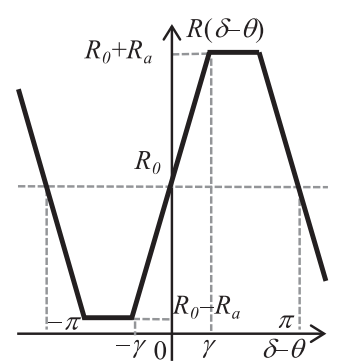

(b)
Fig. 4. Distributions of (a) magnetomotive force and (b) permeance.

ここで, $L_{s}$ : エアギャップの軸方向長さ， $l_{g 1}$ : 高速ロータ と固定磁極片間のエアギャップ長, $r_{g 1}$ : 平均エアギャップ 半径を表す。

起磁力とパーミアンス分布は, $\delta$ を用いて, Fig.4(a),

Fig. 4(b) で定義される。ここで，(12) 式を (11) 式に代入 することで，(13) 式が得られる。

$$
\begin{aligned}
& B=\frac{F(\delta) R(\delta-\theta)}{2 r_{g 1} L_{s} \pi} \ldots \ldots \ldots \ldots \ldots \ldots \ldots \ldots \ldots \\
& W(\theta)=\frac{l_{g 1}}{8 \mu_{0} r_{g 1} L_{s} \pi^{2}} \int_{0}^{2 \pi} F^{2}(\delta) R^{2}(\delta-\theta) d \delta \ldots \ldots
\end{aligned}
$$

また, $F^{2}(\delta)$ と $R^{2}(\delta-\theta)$ をフーリ工級数展開すると, (14), (15) 式で表される。

$$
\begin{aligned}
& F^{2}(\delta)=a_{0 F}+\sum_{n=1}^{\infty} a_{n} \cos 2 n N_{h} \delta \ldots \ldots \ldots \\
& R^{2}(\delta-\theta)=a_{0 R}+\sum_{m=1}^{\infty} b_{m} \sin m N_{s}(\delta-\theta)
\end{aligned}
$$

ここで， $a_{0 F}$ と $a_{0 R}$ は定数を表す。

(14) 式と (15) 式を(13) 式の積分項に代入すると, (16) 式が得られる。

$$
\begin{aligned}
& F^{2}(\delta) R^{2}(\delta-\theta) \\
& =a_{0 F} a_{0 R}+\sum_{n=1}^{\infty} a_{0 R} a_{n} \cos 2 n N_{h} \delta \\
& \quad+\sum_{m=1}^{\infty} a_{0 F} b_{m} \sin m N_{s}(\delta-\theta) \\
& \quad+\sum_{m=1}^{\infty} \sum_{n=1}^{\infty} \frac{a_{n} b_{m}}{2}\left[\sin \left\{\left(2 n N_{h}+m N_{s}\right) \delta-m N_{s} \theta\right\}\right. \\
& \left.\quad-\sin \left\{\left(2 n N_{h}-m N_{s}\right) \delta+m N_{s} \theta\right\}\right] \ldots \ldots \ldots \ldots
\end{aligned}
$$

ここで，(16) 式の右辺第 1 項は， $\theta$ の偏微分でゼロ，第 2, 3，4 項は， $\delta$ の積分でゼロになる。したがって，コギング トルクが発生する条件は，第 5 項がゼロでないことである。 つまり，(17) 式で表されるコギングトルクが，(18) 式が満 たされたときに発生する。

$$
T_{1}(\theta)=-\frac{\partial}{\partial \theta}\left\{\frac{l_{g 1}}{8 \mu_{0} r_{g 1} L_{s} \pi^{2}} \int_{0}^{2 \pi} \sum_{m=1}^{\infty} \sum_{n=1}^{\infty}-\frac{a_{n} b_{m}}{2} \sin \left(m N_{s} \theta\right)\right\}
$$

$$
2 n N_{h}-m N_{s}=0
$$

低速ロータと固定磁極片から生成された高調波磁束によっ て高速ロータに発生するコギングトルク $T_{2}(\theta)$ は, 同様の手 順で求めることができるが，(1)〜 (4) 式と同様の考え方で, $N_{l}, N_{s} \pm N_{l}$ 極対の磁石によるコギングトルクと考えてよ い。なお，ここでは $N_{s}-N_{l}=N_{h}$ とし， $N_{s}+N_{h}$ は比較的周 波数が高いので考慮しないことで, $T_{2}(\theta)$ は単純に低速ロー 夕によって発生するコギングトルクと考えることができる。 ここで, 高速ロータが 1 回転すると, 低速ロータ $N_{l}-G_{r} N_{l}$ 極対が高速ロー夕を通過する。したがって，低速ロータを 固定すると, 低速ロー夕の極対数は, $N_{l}-G_{r} N_{l}$ とみなすこ とができる。このとき, 低速ロー夕による起磁力を $G(\delta-\theta)$ とすると，2つのロータによる起磁力 $F(\delta)+G(\delta-\theta)$ は, (19)式で表すことができる。

$$
\begin{aligned}
& F(\delta)+G(\delta-\theta) \\
& =a_{0 F G}+\sum_{n=1}^{\infty} c_{n} \cos n N_{h} \delta+\sum_{m=1}^{\infty} c_{m} \cos m\left(N_{l}-G_{r} N_{l}\right)(\delta-\theta)
\end{aligned}
$$

ここで， $a_{0 F G}$ : 定数を表す。 2 つロロタ間のパーミア ンス分布を $R_{1}$ （一定）とすると, (13) 式の積分項は, (20) 式で表すことができる。

$$
\begin{aligned}
& (F(\delta)+G(\delta-\theta))^{2} R_{1}^{2} \\
& =c_{0}^{2} R_{1}^{2}+\sum_{n=1}^{\infty} c_{n}^{2} R_{1}^{2} \cos ^{2} n N_{h} \delta \\
& \quad+\sum_{m=1}^{\infty} c_{m}^{2} R_{1}^{2} \cos ^{2} m\left(N_{l}-G_{r} N_{l}\right)(\delta-\theta) \\
& \quad+\sum_{n=1}^{\infty} 2 a_{0 F G} c_{n} R_{1}^{2} \cos n N_{h} \delta \\
& \quad+\sum_{m=1}^{\infty} 2 a_{0 F G} c_{m} R_{1}^{2} \cos m\left(N_{l}-G_{r} N_{l}\right)(\delta-\theta) \\
& \quad+\sum_{m=1}^{\infty} \sum_{n=1}^{\infty} 2 c_{m} c_{n} R_{1}^{2} \cos \left(n N_{h} \delta\right) \cos m\left(N_{l}-G_{r} N_{l}\right)(\delta-\theta)
\end{aligned}
$$

ここで，第 6 項のみがコギングトルクを発生させることが でき，(21) 式に展開できる。

$$
\begin{aligned}
& \sum_{m=1}^{\infty} \sum_{n=1}^{\infty} R_{1}^{2} c_{m} c_{n} \\
& \times\left[\cos \left[\left\{n N_{h}+m\left(N_{l}-G_{r} N_{l}\right)\right\} \delta-m\left(N_{l}-G_{r} N_{l}\right) \theta\right]\right. \\
& \left.+\cos \left[\left\{n N_{h}-m\left(N_{l}-G_{r} N_{l}\right)\right\} \delta+m\left(N_{l}-G_{r} N_{l}\right) \theta\right]\right]
\end{aligned}
$$

(22) 式が満たされたとき, 低速ロータによるコギングト ルク $T_{2}(\theta)$ が発生し, (23) 式で表される。

$$
n N_{h}-m\left(N_{l}-G_{r} N_{l}\right)=0
$$


Table 1. Orders of the cogging torque and constraint.

\begin{tabular}{c|c|c}
\hline & $\begin{array}{c}\text { Orders of } \\
\text { the cogging torque }\end{array}$ & Constraint \\
\hline \multirow{2}{*}{$\begin{array}{c}\text { High-speed } \\
\text { rotor }\end{array}$} & $m\left(N_{l}-G_{r} N_{l}\right)$ & $n N_{h}=m\left(N_{l}-G_{r} N_{l}\right)$ \\
\cline { 2 - 3 } & $m N_{s}$ & $2 n N_{h}=m N_{s}$ \\
\hline $\begin{array}{c}\text { Low-speed } \\
\text { rotor }\end{array}$ & $m\left(N_{l}-G_{r} N_{l}\right)$ & $n N_{h}=m\left(N_{l}-G_{r} N_{l}\right)$ \\
\cline { 2 - 3 } & $m N_{s}$ & $2 n N_{l}=m N_{s}$ \\
\hline
\end{tabular}

$$
\begin{aligned}
T_{2}(\theta)= & -\frac{\partial}{\partial \theta}\left\{\frac{l_{g 1}}{8 \mu_{0} r_{g 1} L_{s} \pi^{2}}\right. \\
& \left.\times \int_{0}^{2 \pi} \sum_{m=1}^{\infty} \sum_{n=1}^{\infty} R_{1}^{2} c_{m} c_{n} \cos m\left(N_{l}-G_{r} N_{l}\right) \theta\right\}
\end{aligned}
$$

以上より，高速ロータに発生するコギングトルク $T(\theta)$ は， (24) 式で表される。

$$
\begin{aligned}
T(\theta)= & -\frac{\partial}{\partial \theta}\left[\frac{l_{g 1}}{8 \mu_{0} r_{g 1} L_{s} \pi^{2}}\right. \\
& \times\left\{\int_{0}^{2 \pi} \sum_{m=1}^{\infty} \sum_{n=1}^{\infty} R_{1}^{2} c_{m} c_{n} \cos m\left(N_{l}-G_{r} N_{l}\right) \theta\right. \\
& \left.\left.-\int_{0}^{2 \pi} \sum_{m=1}^{\infty} \sum_{n=1}^{\infty} \frac{a_{n} b_{m}}{2} \sin \left(m N_{s} \theta\right)\right\}\right] \ldots \ldots
\end{aligned}
$$

低速ロー夕に発生するコギングトルクも同様に求めること ができ,コギングトルクの次数成分をまとめた結果を Table 1 に示す。

\section{4. 伝達トルク解析}

〈4・1〉 解析モデル コギングトルクに含まれる次数成 分を検証するため, 三次元有限要素法を用いて解析を行った。 本研究で用いた表面磁石型磁気減速機の仕様を Table 2, 主 要な寸法を Table 3, 概観を Fig. 5 に示す。このモデルでは, 14 個の固定磁極片は, 電磁鋼板の厚みに相当する $0.5 \mathrm{~mm}$ 幅のフラックスパスにより，互いに連結されている。

〈4·2〉 解析結果 伝達卜ルク解析結果を Fig. 6, 2 つ のロータに含まれるコギングトルク次数を Fig. 7, Fig. 8 に 示す。なお, 以降, 図中の「H. C.」は Harmonic component （高調波成分）を表す。

高速ロータ，低速ロータのコギングトルクはそれぞれ， $0.013 \mathrm{Nm}, 0.029 \mathrm{Nm}$ で, 伝達トルクの $0.5 \%$ 程度と非常に 小さい。これは, 高速ロータでは固定磁極片のフラックス パスによる閉スロット構造が影響し, 低速ロータでは平板 形状の永久磁石によりエアギャップのパーミアンスの変化 が比較的滑らかであったためと推測できる。

また，Table 1 に記載の成分が確認できるが，そうでない 成分は, 高速もしくは低速ロー夕の極対数, 固定磁極片数 の高調波成分で，メッシュの誤差から発生していると推測 できる。
Table 2. Specification of the SPM-type magnetic gear in this study.

\begin{tabular}{l|c}
\hline Number of pole pairs in the high-speed rotor & 4 \\
\hline Number of pole pairs in the low-speed rotor & 10 \\
\hline Number of stationary pole pieces & 14 \\
\hline Gear ratio & -2.5 \\
\hline
\end{tabular}

Table 3. Major dimensions (unit: $\mathrm{mm}$ ).

\begin{tabular}{l|c}
\hline Outer radius of the high-speed rotor & $\mathrm{R} 23$ \\
\hline Inner radius of the stationary pole pieces & $\mathrm{R} 24$ \\
\hline Outer radius of the stationary pole pieces & $\mathrm{R} 34$ \\
\hline Inner radius of the low-speed rotor & $\mathrm{R} 35$ \\
\hline Outer radius of the low-speed rotor & $\mathrm{R} 45$ \\
\hline Axial length & 26 \\
\hline
\end{tabular}

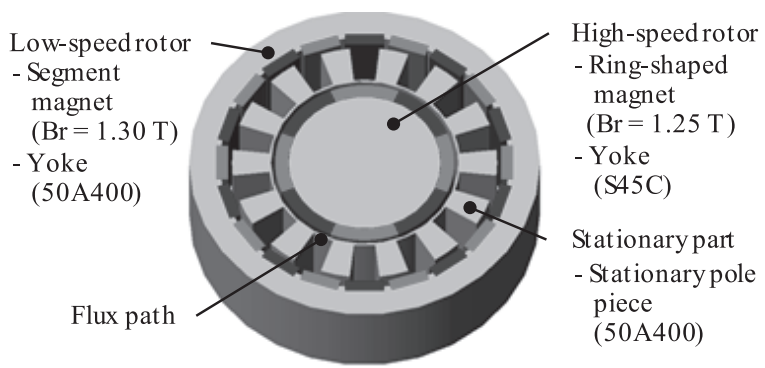

Fig. 5. Analysis model in this study.

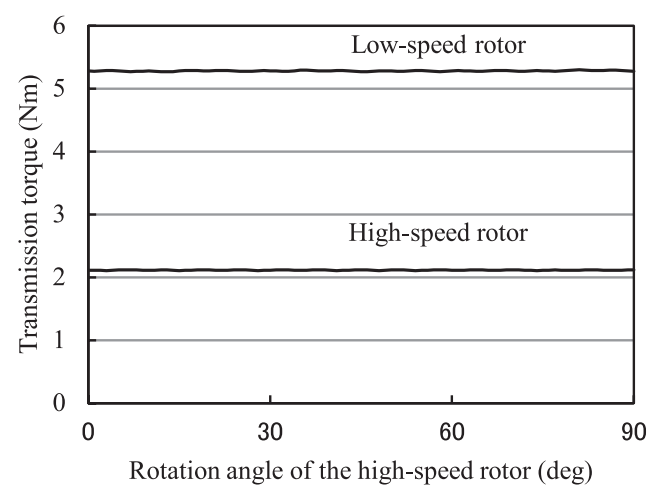

Fig. 6. Computed synchronous transmission torque.

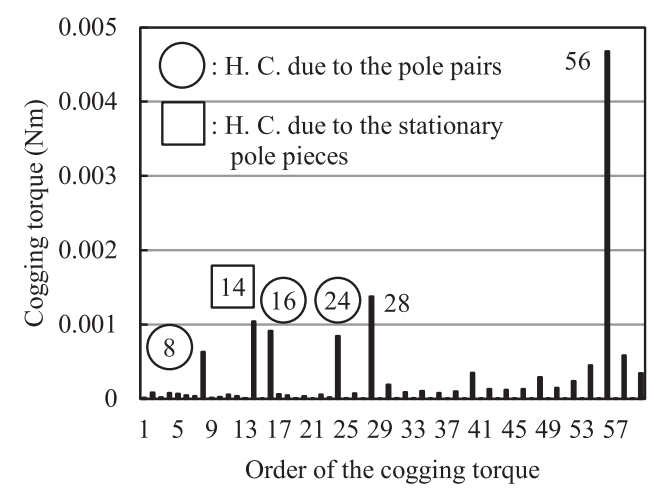

Fig. 7. Order of the cogging torque of the high-speed rotor. 


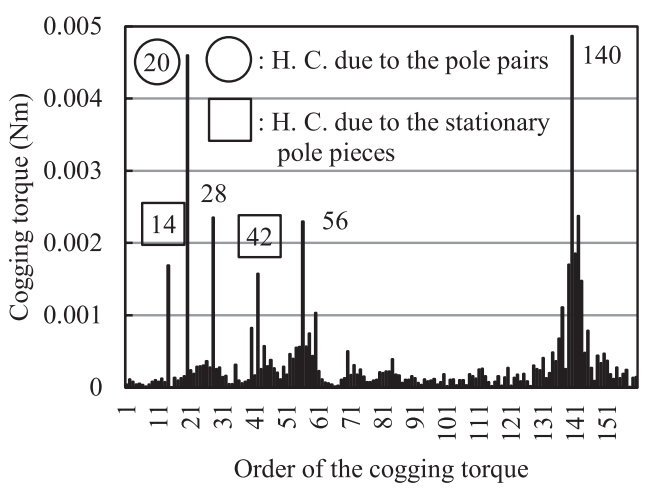

Fig. 8. Order of the cogging torque of the low-speed rotor.

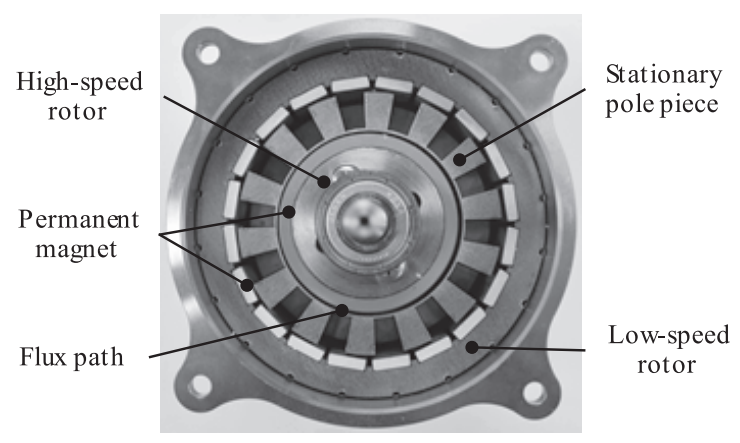

Fig. 9. Overview of the prototype magnetic gear.

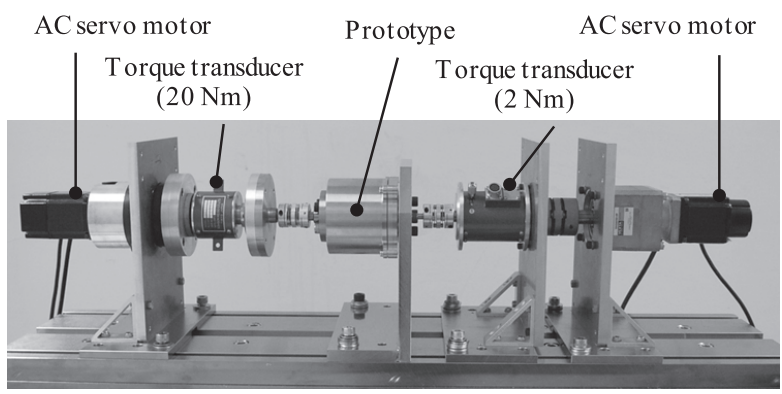

Fig. 10. Photograph of torque measuring system.

\section{5. 試作機によるコギングトルク次数の検証}

〈5・1〉 試作機とトルク測定装置コギングトルク次 数の理論式の検証を行うため, Fig. 9 に示す試作機を組立 て, Fig. 10 に示すトルク測定装置を用いて，伝達トルク測 定を行った。このとき, 減速比に従った回転速度を 2 つの サーボモータに与えた。

〈5・2〉測定結果 渦電流損の影響を抑制するため, 高 速ロータを $0.5 \mathrm{rpm}$ ，低速ロータを高速ロータとは反対向 きに $0.2 \mathrm{rpm}$ で回転させたときの伝達トルクを Fig. 11 に示 す。また，2つのロータのコギングトルクに含まれる次数 成分を Fig. 12, Fig. 13 に示す。

高速ロータと低速ロータのコギングトルクはそれぞれ, $0.064 \mathrm{Nm}, 0.371 \mathrm{Nm}$ で，解析值より大きい。寸法や組立 て誤差以外の要因として, AC サーボモータによって発生 する測定系のノイズが考えられる。このノイズによる最大 トルク誤差は，高速側で約 $0.003 \mathrm{Nm}$ ，低速側で約 $0.08 \mathrm{Nm}$

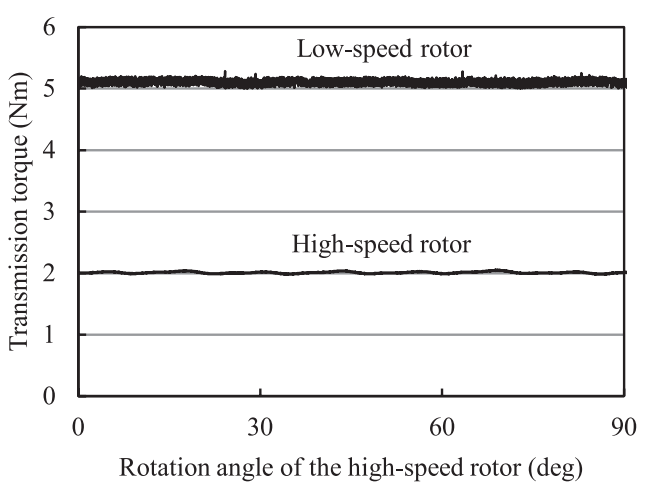

Fig. 11. Measured synchronous transmission torque.

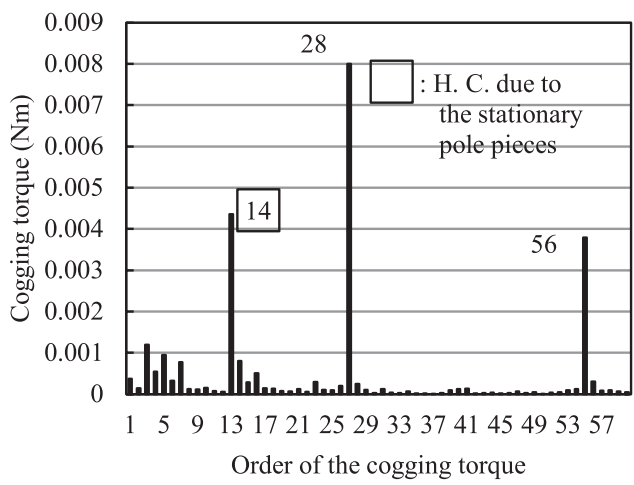

Fig. 12. Order of the cogging torque of the high-speed rotor.

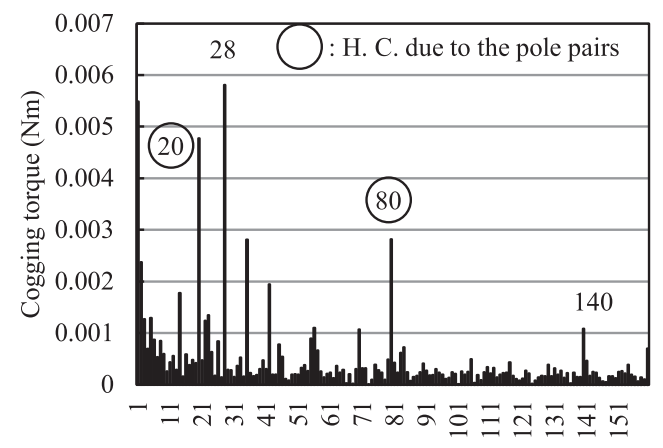

Order of the cogging torque

Fig. 13. Order of the cogging torque of the low-speed rotor.

で，低速側に影響が現れやすい。また，高速ロータのコギ ングトルクでは, 28 次成分が最も大きく, 解析結果の約 6 倍であった。同様に，低速ロータのコギングトルクにおい ても, 28 次成分が最も大きく, 解析結果の約 3 倍であった。 28 次は Table 1 に記載されている成分の上，固定磁極片の 寸法および組立て誤差から発生する高調波成分でもある。 したがって，試作機の固定磁極片の寸法および組立て誤差 により，高速ロータおよび低速ロータのコギングトルクの 28 次成分が増加したと考えられ，また，(24) 式の妥当性が 実験により示された。

\section{6. コギングトルク低減}

〈6・1〉スキューを施した有限要素モデル＼cjkstart最大伝達卜 


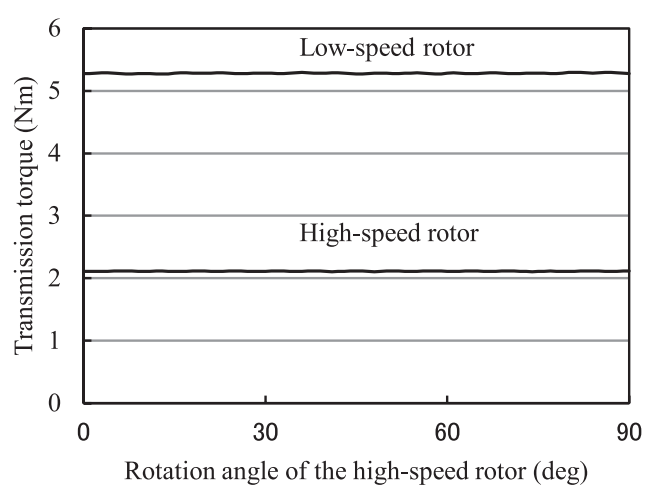

Fig. 14. Computed synchronous transmission torque.

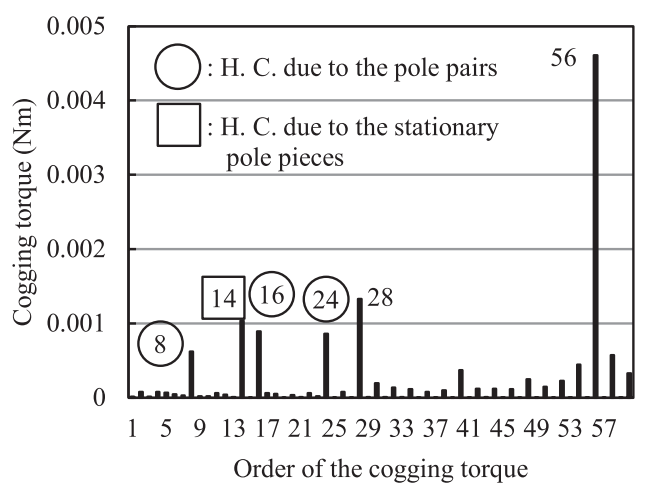

Fig. 15. Order of the cogging torque of the high-speed rotor.

ルクに対するコギングトルクは，低速ロータより高速ロー 夕の方が大きい。したがって，高速ロータのコギングトル クを低減するため，2 段積みスキューを施したロー夕を採用 する。このとき，寸法や組立て誤差の影響を排除し，理論 的に最も大きいコギングトルク成分は Fig. 7 から 56 次であ ることがわかる。そこで，56 次成分を低減するため，軸方

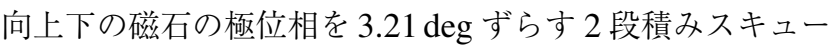
を採用する。

Fig. 14 に伝達トルクの解析結果を示す。また, コギング トルクに含まれる次数成分を Fig. 15, Fig. 16 に示す。高速 ロータと低速ロータのコギングトルクはそれぞれ, $0.012 \mathrm{Nm}$ と $0.028 \mathrm{Nm}$ で，高速ロータのコギングトルクは $0.001 \mathrm{Nm}$ しか低減されなかった。明らかな低減効果が得られなかっ た原因は，低減を図った 56 次成分がほとんど低減されな かったことである。ここで，56 次成分がほとんど低減され なかった要因として, 組立て誤差が存在しない解析では, 寸 法や磁束密度分布に影響を与えるメッシュ誤差が挙げられ る。伝達トルクに比べてコギングトルクが $0.5 \%$ 程度と非常 に小さいことからも，メッシュ誤差の影響が支配的になっ たと推測できる。

〈6・2〉 スキュー品の測定結果２段積みスキューを施 したロータの写真を Fig. 17 に示す。また，伝達トルク測定 結果を Fig. 18，コギングトルクに含まれる次数を Fig. 19， Fig. 20 に示す。

高速ロータと低速ロータのコギングトルクはそれぞれ，

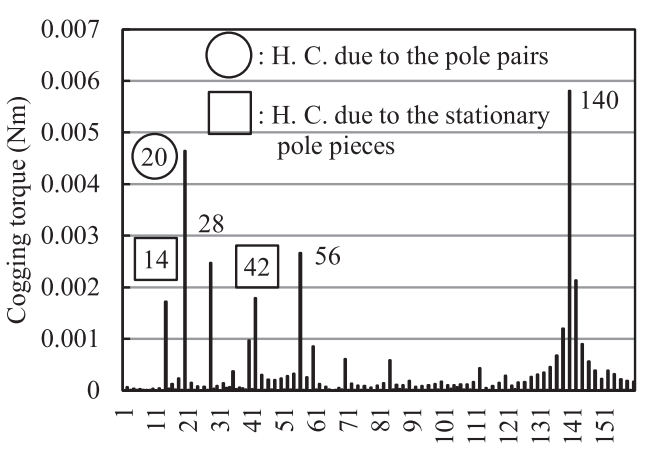

Order of the cogging torque

Fig. 16. Order of the cogging torque of the low-speed rotor.

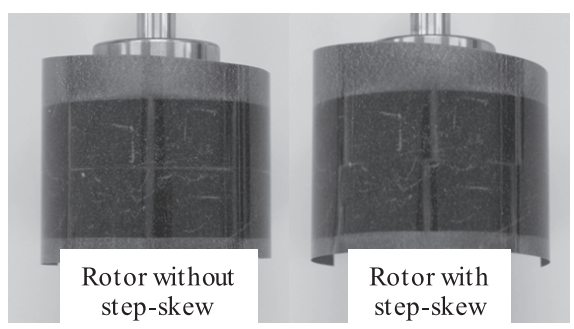

Fig. 17. Comparison of visualized magnetization.

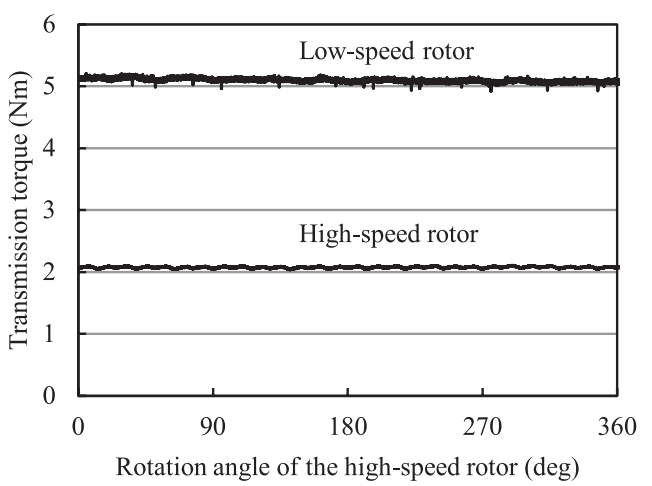

Fig. 18. Measured synchronous transmission torque.

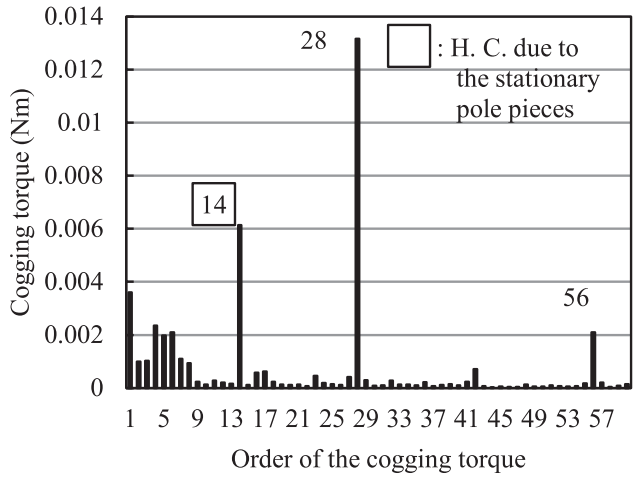

Fig. 19. Order of the cogging torque of the high-speed rotor.

$0.067 \mathrm{Nm}, 0.292 \mathrm{Nm}$ で, 低減を図った高速ロータのコギン グトルクは解析結果同士の比較と同様，ほとんど変化がな かった。そのため，高速ロータのコギングトルクに含まれ る 56 次成分は半減されているが，2段積みスキューを行っ 


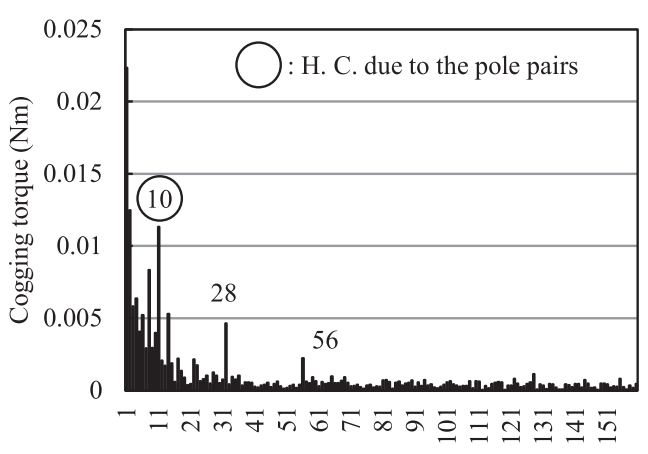

Order of the cogging torque

Fig. 20. Order of the cogging torque of the low-speed rotor.

ていないモデルの解析值と測定值の差（約 $0.05 \mathrm{Nm}$ ）を誤 差レベルとみなすと, 高速ロータの寸法や組立て誤差, さ らに AC サーボモー夕による測定系のノイズの影響で偶然 にも半減されたと考えてよい。

\section{7. 結 論}

SPM 型磁気減速機の動作原理および伝達卜ルク特性を定 式化し，三次元有限要素法㧍よび実験によって，コギング トルクに含まれる次数成分の妥当性を示した。

また，2段積みスキューによる高速ロータのコギングトル ク低減を提案したが，解析では，メッシュ誤差の影響によ り明確な低減効果が得られず，試作機による検証でも，高 速ロー夕の寸法や組立て誤差，さらに AC サーボモー夕に よる測定系のノイズの影響を受け，理論的には低減可能で あるが，明確な低減効果が得られなかった。本稿のモデル では，固定磁極片に設置されたフラックスパスにより，2段 積みスキューを行わなくてもコギングトルクが伝達トルク の $0.5 \%$ 程度と非常に小さいため, 誤差が支配的になりやす いことが影響したと考えることができる。今後，高速ロー 夕と低速ロータのコギングトルクを同時に低減する構造を 提案する予定である。

(平成 22 年 8 月 4 日受付，平成 22 年 10 月 9 日再受付)

\section{文献}

(1) K. Atallah and D. Howe: "A novel high-performance magnetic gear", IEEE Trans. Magn., Vol.37, No.4, pp.2844-2846 (2001)

(2) P.O. Rasmussen, T.O. Andersen, F.T. Joergensen, and O. Nielsen: "Development of a High-Performance Magnetic Gear", IEEE Trans. IA, Vol.41, No.3, pp.764-770 (2005)

(3) K. Atallah, J. Wang, S. Mezani, and D. Howe: "A Novel High-Performance Linear Magnetic Gear”, IEEJ Trans. IA, Vol.126, No.10, pp.1352-1356 (2006)

(4) M. Yamamoto, K. Hirata, and M. Muramatsu: "Study of a new magnetic gear", AEM Press, Vol.17, No.2, pp.188-193 (2009) (in Japanese) 山本優文・平田勝弘・村松雅理：「新しい磁気伝達減速機構に関する 研究」, 日本 AEM 学会論文誌, Vol.17, No.2, pp.188-193 (2009)

(5) K. Hirata, M. Yamamoto, and M. Muramatsu: "Proposal of an Axial Gap Magnetic Gear", IEEJ Trans. IA, Vol.130, No.6, pp.802-807 (2010) (in Japanese)

平田勝弘・山本優文・村松雅理：「アキシャルギャップ形磁気減速 機」, 電学論 D, Vol.130, No.6, pp.802-807 (2010)

(6) A. Ide, K. Hirata, H. Ishiguro, Y. Nakata, M. Muramatsu, and N. Niguchi: "Dynamic Analysis of New Linear Magnetic Gear Employing 3D-FEM", in Proc. Technical Meeting on Linear Drives, 2010, LD-10-015 (2010) (in Japanese)

井出充洋 - 平田勝弘 - 石黒 浩 - 仲田佳弘 - 村松雅理 - 新口 昇 : 「三次元有限要素法を用いた新構造リニア磁気伝達減速機の動作特 性解析」,リニアドライブ研究会, LD-10-015 (2010)

(7) N. Niguchi, K. Hirata, M. Yamamoto, and M. Muramatsu: "Study on Cogging Torque Reduction in a Hybrid-Type Magnetic Gear", IEEJ Trans. IA, Vol.130, No.5, pp.692-698 (2010) (in Japanese)

新口昇・平田勝弘・山本優文・村松雅理 :「ハイブリッド型磁気伝 達減速機構のコギングトルク低減に関する研究」, 電学論 D, Vol.130, No.5, pp.692-698 (2010)

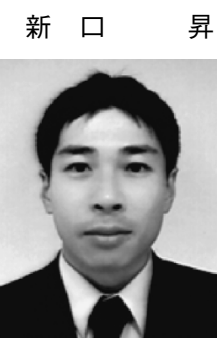

昇（正員） 1975 年 9 月 25 日生。 1998 年 3 月大阪 大学機械工学科卒業。2000 年 3 月同大学大学院 工学研究科修士課程修了。2009 年 10 月同大学大 学院工学研究科博士課程入学, 現在に至る。主と して回転機の研究に従事。IEEE 学生員他。

平 田勝 弘 (上級会員) 1958 年 4 月 10 日生。1 982 年 3 月大

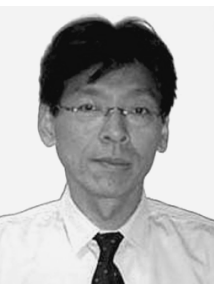
阪大学機械工学科卒業。同年 4 月松下電工 (株), 技術研究所勤務。2005 年大阪大学大学院工学研究 科知能・機能創成工学専攻・助教授を経て，2007 年同大教授, 現在に至る。主として電磁アクチュ エータ，センサデバイス，有限要素法を用いた電 磁界解析に関する研究に従事。工学博士。2003 年 文部科学大臣賞 (研究功績者) 受賞。2004 年オー 厶技術賞受賞。2007 年電気学会電気学術振興賞 (進歩賞) 受賞。2009 年電気学会電気学術振興賞 (論文賞) 受賞。IEEE 会員他。

早川裕一

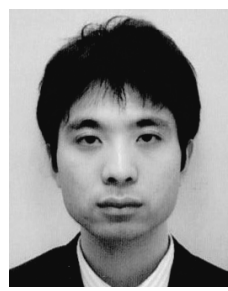

(学生員) 1986 年 4 月 20 日生。 2009 年 3 月大 阪大学応用理工学科卒業。同年 4 月同大学大学院 工学研究科入学, 現在に至る。主として回転機の 研究に従事。 